Ann. Biol. anim. Bioch. Biophys., 1978, 18 (4), 877-882.

\title{
The gonadal cycle of the captivity-reared hermaphroditic teleost Sparus aurata (L.) during the first two years of life
}

\author{
par Y. ZOHAR ('), M. ABRAHAM, H. GORDIN * \\ The Hebrew University of Jerusalem, Jerusalem, Israel \\ * Israel Oceanographic and Limnological Research Lid., Mariculture Laboratory \\ POB 1212, Eilat, Israel.
}

Summary. The gonadal cycle of the hermaphroditic teleost Sparus ourata reared in captivity was studied during the first two years of life. Until the age of 8 months, the dorsal ovarian part of the bisexual gonad was dominant. Towards the first breeding season at the end of the first year of life, the ventral testicular part of the gonad proliferated, forming a mature testis. At the end of the first breeding season, all the fish began to undergo sex reversal. From the age of 17 months, development proceeded in two directions : in about 80 p. 100 of the population the sex reversal process was completed and the individuals developed into females; in the rest of the population the sex reversal process was not completed and the individuals developed into males.

\section{Introduction.}

Normal hermaphroditism and sex reversal are well-known phenomena in Teleostei (Atz, 1964 ; Reinboth, 1970). Pasquali (1941) and d'Ancona (1941,1949), studying the gonadal cycle of Sparus aurata caught in the Adriatic Sea, demonstrated protandrous hermaphroditism in this species. These authors found that the entire population functions as males at the end of the second year of life, then changes sex and performs as females from the end of the third year.

The goal of the present research was to carry out an histological study of the gonadal cycle of $S$. aurata, based on captivity-reared fish of known age.

\section{Materials and methods.}

Fry of S. aurata about $20 \mathrm{~mm}$ long were collected in their natural habitat in the Mediterranean sea once a year at the end of March. They were stocked at densities up to $5 \mathrm{~kg} / \mathrm{m}^{3}$ in outdoor experimental tanks according to 2 age classes, i. e. 4 months

(1) Present address : I.N.R.A., Laboratoire de Physiologie des Poissons, 78350 Jouy-en-Josas, France. 
to 1 year and 1 year or older. An open circulation system supplied the tanks with sea water from the Gulf of Eilat. The fish were exposed to the natural photoperiod at water temperatures of $21^{\circ} \mathrm{C} \pm 2$ all the year round; water salinity was 40 p. 100. Fish were fed once a day ad libitum on artificial pellets. From April 1975 though June 1976, monthly gonad samples were taken from 5 to 10 individuals in each of the 2 age classes. A total of 245 fish were sampled.

Immediately after decapitation, gonads were removed from the fish. The tissues used for histological studies were fixed in either Bouin or Karnovsky (1965) solution. Tissue processed in Bouin solution was embedded in paraffin, while that treated in Karnovsky solution was post-fixed with 1 p. $100 \mathrm{OsO}_{4}$ and embedded in Epon 812. Staining procedures included Azan, hematoxylin and eosin, methylene blue and toluidine blue.

\section{Results.}

4 to 8-month old fish.

During the period from 4 to 8 months of age, the early development of the bisexual gonad can be followed. At the age of 4 months, the gonad is undifferentiated, and protogonial nests are unevenly spread throughout the gonad, concentrated mainly in the vicinity of the central cavity which is dorsally located.

A month later, a topographical differentiation becomes evident in the gonadal cross-section. The gonad is divided into dorsal and ventral regions. The dorsal region, which contains the gonadal central cavity, constitutes about 90 p. 100 of the gonadal cross-section area. This is the future ovarian part of the gonad. The ventral region, not invaded by the central cavity, is the future testicular part of the gonad.

At the age of 8 months (fig. 1), the dorsal part of the gonad has the structure of a young ovary. It consists of lamellar folds densely packed with oogonia. At this stage, the oogonia begin to degenerate; the process begins in the centrum and spreads out centrifugally, affecting all the oogonia except for a rim of oogonia near the juxtacavicular part of the ovigerous folds. Between these remaining oogonia and the central cavity there is a visible layer of squamosial epithelium cells. The ventral part of the gonad is populated by nests containing spermatogonia.

\section{9 to 12-month old fish.}

During the period from 9 to 12 months of age, the ovarian part of the gonad regresses while the testicular one develops. At 9 months, the dorsal part of the gonad is still dominant. Its oogonial degeneration process is finished; all the lamellae, which a month earlier were densely populated by oogonia, appear now to be empty except for the above-mentioned oogonia near the central cavity.

In 10 to 11-month old fish, active spermatogenesis takes place in the ventral part of the gonad. The testicular part increases in size, engulfing the ovarian part in which the lamellar cavities have disappeared (fig. 2). At the end of the first year of life, in the first breeding season, the ventral part of the gonad forms a functional testis. In the ovarian component, the oogonial rim near the central cavity is still visible. 
13 to 16 -month old fish.

The period from 13 to 16 months of age is characterized by the beginning of a sex reversal process. The testicular part of the gonad is spent and remains latent. Throughout this period, it is densely packed with spermatogonia. The ovarian part of the
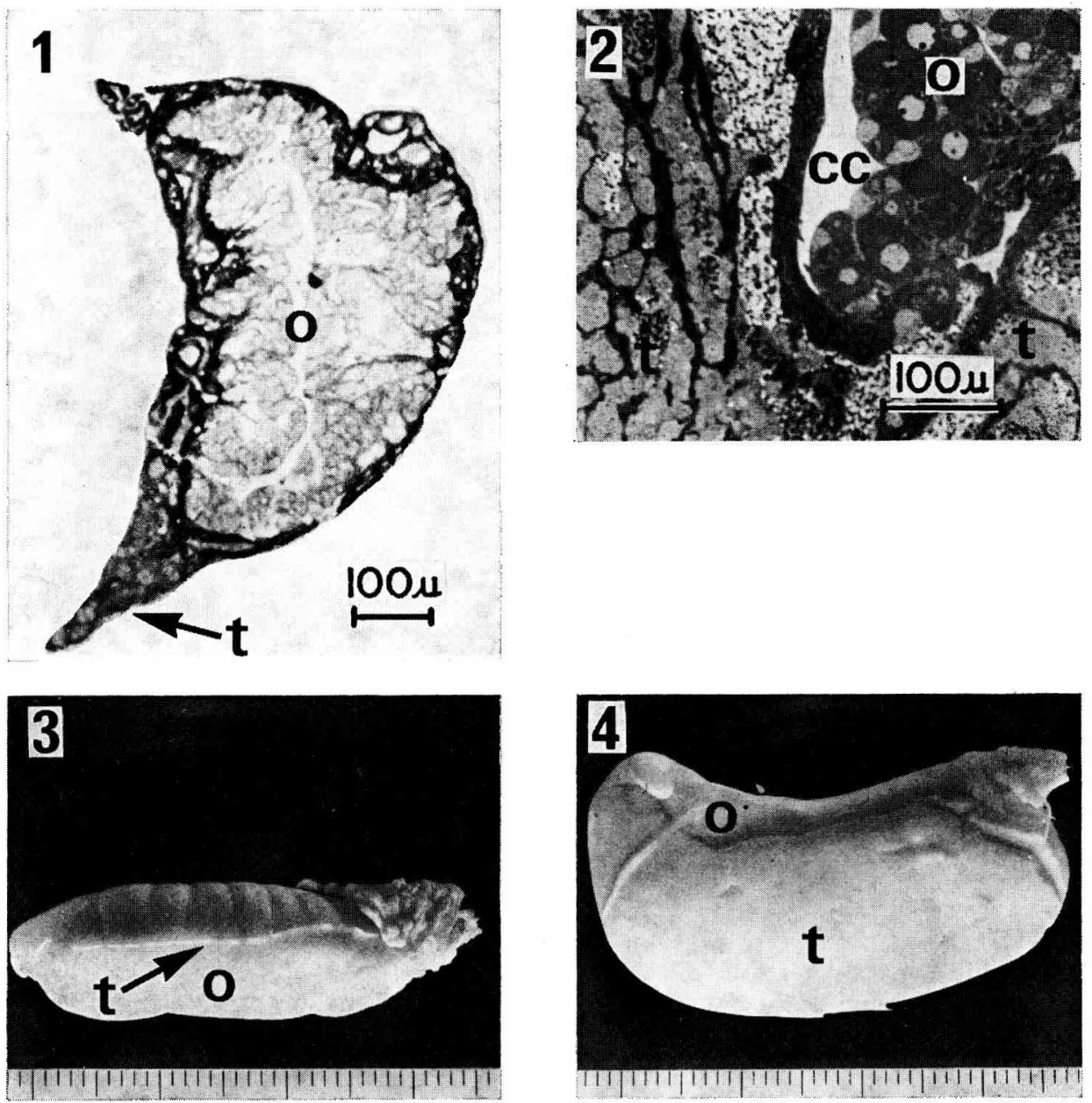

FIG. 1. - Transverse section in the gonad of an 8-month old fish.

The gonad is divided into a dominant dorsal ovarian part $(0)$ and a ventral testicular part ( $t)$.

FIG. 2. - The testicular part of the gonad ( $t$ ) envelops the ovarian one $(0)$ in which oogonia and primary oocytes line the central cavity $(\mathrm{CC})$ in a 10-month old specimen.

FIG. 3. - Gonad of a 24-month old mature female. Degenerated testis ( $t)$ is ventrally attached to the fully developed ovary $(0)$. The millimetric scale is shown.

FIG. 4. - Gonad of a 24-month old mature male.

Functional testis (t) envelops the remains of the ovary $(0)$. The millimetric scale is shown. 
gonad undergoes intensive growth and the oogonia start to undergo oogenesis. As a result, ovigerous lamellae develop and the ovarian part of the gonad constitutes 85 p. 100 of the gonadal cross-section area.

\section{7 to 24-month old fish.}

During the period from 17 to 24 months of age, two opposite patterns develop. In about 80 p. 100 of the individuals sampled, the dorsal ovarian part of the gonad continues to develop; the oocytes finish their previtellogenetic growth and undergo vitellogenesis. Simultaneously, the ventral testicular part of the gonad progressively degenerates and its spermatogonia undergo rapid necrosis. At 23 to 24 months the second breeding season, the gonad of these fish consists of a dorsal mature ovary and a ventral degenerated rudimentary testis (fig. 3). In the remaining 20 p. 100 of the sampled population, the reverse happens. Spermatogenesis starts in the ventral testicular component of the gonad which increases in size. The ovarian component of the gonad undergoes degeneration and the previtellogenetic oocyles populating it become atretic. At 23 to 24 months, the ventral part of the gonad is a functional testis, enveloping almost completely the remains of the dorsal ovary (fig. 4).

\section{Discussion.}

As previously shown by Pasquali (1941), D'Ancona $(1941,1949)$ and Reinboth (1962), this study demonstrates that $S$. aurata is a protandrous hermaphroditic species. Nevertheless, previous to the functional male stage we followed a phase of oogonial proliferation which results in an ephemeral ovary at the age of seven to eight months. In addition, our data is some what different as compared to earlier studies : 1) Two phases, not previously noted, are described here : a) the enlargement of the dorsal part of the gonad into the form of a young ovary in 7 to 8-month old fish and $b$ ) the subsequent degeneration of the oogonia in 8 or 9-month old fish. The decrease in the protogonia frequency mentioned by Pasquali (1941) and D'Ancona (1941) corresponds to an earlier stage in the gonadal development, previous to central cavity formation and is not described in the present study. 2) According to Pasquali (1941) and D'Ancona (1941), S. aurata reaches first complete sexual maturify at the end of the second year of life when all the fish function as males. The present study shows that by the end of the first year of life, all the fish function as males. 3) According to Pasquali (1941) and D'Ancona (1941), during the third year of life all the fish undergo sex reversal and from the third breeding season on, they function as females. Our study demonstrated that at the end of the first breeding season all the fish start to change sex. In the second half of the second year, a split occurs in the gonadal development, resulting in 80 p. 100 females and 20 p. 100 males in the second breeding season.

The discrepancies between our study and those of Pasquali (1941) and D'Ancona (1941) could be explained by one or more of the following : 1) There may be differences in detail of the gonadal cycle between fish growing in their natural habitat, as mainly used by Pasquali (1941) and by D'Ancona (1941), and our fish reared in captivity. Some environmental conditions under which the fish were maintained in our study, i. e., relatively high and constant water temperature throughout the year 
and daily feeding, may explain their accelerated gonadal development and precocious sexual maturation as compared to the fish studied by Pasquali (1941) and D'Ancona (1941). 2) There may be differences in detail of the gonadal cycle between fish originating in the Adriatic sea as used by Pasquali (1941) and by D'Ancona (1941) and our fish originating in the eastern Mediterranean. 3) The exact age of some of the fish sampled by Pasquali (1941) and by D'Ancona (1941) was perhaps uncertain, in contrast to the exact age determination in the present study. 4) Pasquali (1941) and D'Ancona (1941), not being able to capture successive fish samples throughout the year, possibly lacked a few phases of the gonadal development; however in the present study a routine monthly sampling supplied details of the entire process.

The present study demonstrates the lability of the sex reversal process. Although in all the fish over one-year old, which at the age of twelve months were functional males, the testicular tissue begins to regress and the ovary to develop, the sex reversal process is not completed in all of them. Some of the fish redevelop the testis and become functional males at the age of two years. This fluctuation between masculinity and femininity may be the result of a social control of the sex reversal process, a mechanism which ensures the appropriate male-to-female ratio in the population.

Through an inhibitory effect caused by fish with a more developed ovary, the control mechanism may act on the further development of the gonadal ovarian part in fish in which this part is less developed. Hence, in the inhibited individuals, the ovary starts to degenerate while the latent testis develops. In the other individuals, the ovary matures while the testis degenerates. A similar control of the sex reversal process was studied in a few protogynous hermaphroditic teleosts (Robertson, 1972 ; Fishelson, 1970, 1975 ; Warner, Robertson and Leigh, 1975). A detailed experimental study is needed to confirm this hypothesis.

Symposium sur la Reproduction des Poissons Paimpont, France, 19-21 septembre 1977.

Résumé. L'étude du cycle sexuel du poisson téléostéen hermaphrodite Sparus aurata a été réalisée jusqu'à l'âge de 2 ans sur des animaux élevés en captivité. Jusqu'à 8 mois, c'est la composante ovarienne, en position dorsale, qui est prépondérante dans la gonade bisexuée A l'approche de la première saison de reproduction (fín de la première année), la composante testiculaire, en position ventrale, prolifère et forme un testicule mature. En fin de première saison de reproduction, une inversion sexuélle s'ébauche chez tous les individus. A 17 mois, deux évolutions sont possibles : chez environ 80 p. 100 des individus le processus d'inversion sexuelle s'achève et donne des femelles; chez les individus restants, l'inversion demeure incomplète, et le développement se fait à nouveau dans le sens mâle.

\section{References}

ATZ J. W., 1964. Intersexuality in fishes, 145-232. In ARMSTRONG C. N., MARSHALL A. J., Intersexuality in vertebrates including man, Acad. Press, New York.

D'ANCONA U., 1941. Ulteriori osservazioni e considerazioni sull'ermafroditismo ed il differenziamento sessuale dell'orata (Sparus auratus L.). Pubbl. Staz. Zool. Napoli, 18, 313-336.

D'ANCONA U., 1949. II differenziamento della gonade e l'inversione sessuale degli sparidi. Arch. Oceanogr. Limnol., 6, 97-163.

FISHELSON L., 1970. Protogynous sex reversal in the fish Anthias squamipinnis (Teleostei : Anthiidae) regulated by the presence or absence of a male fish. Nature, 227, 90-91. 
FISHELSON L., 1975. Ecology and physiology of sex reversal in Anthias squamipinnis (Peters) (Teleostei : Anthiidae), 204-294. In REINBOTH R., Intersexuality in the animal kingdom. Springer Verlag, Berlin.

KARNOVSKY M. J., 1965. A formaldehyde-glutaraldehyde fixative of high osmolarity for use in electron microscopy. J. Cell Biol., 27, 137A-138A.

PASQUALI A., 1941. Contributo allo studio dell'ermafroditismo e del differenziamento della gonada nell'orata (Sparus auratus L.). Pubbl. Staz. Zool. Napoli, 18, 282-312.

REINBOTH R., 1962. Morphologische und funktionelle Zweigeschlechtlichkeit bei marinen Teleostiern (Serranidae, Sparidae, Centracanthidae, Labridae). Zool. Jb. (Physiol.), 69, 405-480.

REINBOTH R., 1970. Intersexuality in fishes. Mem. Soc. Endocrinol., 18, 515-541.

ROBERTSON D. R., 1972. Social control of sex reversal in a coral reef fish. Science, 177, 1007-1009.

WARNER R. R., ROBERTSON D. R., LEIGH E. G. Jr., 1975. Sex change and sexual selection. The reproductive biology of a labrid fish is used to illuminate a theory of sex change. Science, 190, 633-638. 